\title{
Optimalisasi Zakat Sebagai Instrumen Modal Sosial Guna Mengatasi Masalah Kemiskinan Di Indonesia
}

\author{
Dzikrulloh ${ }^{1}$, Arif Rachman Eka Permata ${ }^{2}$ \\ Lecturerst Master of Islamic Economics, Trunojoyo University of Madura ${ }^{1}$ \\ Student Master of Economics, Trunojoyo University of Madura ${ }^{2}$ \\ dzikrulloh@trunojoyo.ac.id ${ }^{1}$, arifrachman2594@gmail.com²
}

DOI: https://doi.org/10.21107/dinar.v5i1.5127

\begin{abstract}
Abstrak
Perpres Nomor 18 tabun 2007 menyebutkan babwa sasaran pembangunan ekonomi tabunan Indonesia diarabkan untuk mendorong pertumbuban ekonomi dalam rangka memperluas lapangan pekerjaan dan mengurangi tingkat kemiskinan. Berimplikasi pada pemerataan pendapatan, zakat memiliki potensi strategis yang layak dikembangkan menjadi salab satu instrumen pemerataan pendapatan di Indonesia khusunya dalam mengatasi masalah ekonomi. Fokus penelitian ini adalah bagaimana mengoptimalkan lembaga amil zakat untuk meningkatkan kesejabteraan masyarakat dan mengurangi tingkat kemiskinan. Metode penelitian, artikel ini menggunakan pendekatan kualitatif dengan jenis penelitian studi literatur.

Hasil dari artikel ini memberikan diskripsi bahwa potensi zakat yang begitu besar di Indonesia harus dioptimalkean secara maksimal. penerapan good corporat governence pada lembaga amil zakat, digitalisasi sistem pengelolaan dan melakukan sinergi kolaborasi dan kerjasama denga lembaga lain yang sesuai dengan visi dan misi lembaga amil zakat akan mendorong kesadaran kepercayaan masyarakat pada lembaga amil zakat dan memberikan kemudahan dalam pengelolaan, penghimpunan dan pendistribusian dana zakat sebingga dapat meningkatkan muzakeki sekaligus meningkatnya dana zakat yang selanjutnya dapat didistribusikan dan dilaporkan secara transparan dan akuntabel.
\end{abstract}

Kata Kunci: zakat, modal sosial, kemiskinan. 


\section{Pendahuluan}

Kemiskinan masih menjadi permasalahan mendasar yang dihadapi oleh bangsa Indonesia (Azhar, dkk, 2017: 16). Penyebab kemiskinan dapat dilihat dari beberapa kondisi sosial yang mencakup berbagai aspek kehidupan yang berbeda seperti pengangguran, kesehatan yang buruk, kurangnya pendidikan, kerentanan, ketidakberdayaan atau sosial.

Data yang dikeluarkan oleh World Meters "Population of Indonesia", 2017 menyebutkan bahwa, jumlah penduduk Indonesia pada tahun 2017 mencapai 264.915.905 jiwa. Data dari BPS, 2018 menyebutkan bahwa dari jumlah tersebut, penduduk miskin di Indonesia mencapai 20.946,38 jiwa dan jumlah penduduk miskin di provinsi Jawa Timur sebesar 2.999 .57 jiwa.

Pemerintah Indonesia melalui Perpres Nomor 18 tahun 2007 telah merumuskan sasaran pembangunan ekonomi tahunan Indonesia diarahkan untuk mendorong pertumbuhan ekonomi dalam rangka memperluas lapangan pekerjaan dan mengurangi tingkat kemiskinan (Fathurrahman, 2012). Hal ini memang sudah menjadi kewajiban pemerintah bahwa suatu negara dikatakan berhasil dalam pembangunan jika angka kemiskinan dapat ditekan semakin rendah sebaik mungkin. Oleh karena itu, mengatasi kemiskinan adalah tantangan yang dihadapi oleh setiap negara. Tingkat kemiskinan dapat dijadikan tolak ukur apakah negara tersebut termasuk negara maju, berkembang ataukah miskin. Dengan kata lain, tingkat kesejahteraan suatu negara dipengaruhi oleh besarnya prosentase kemiskinan di negara tersebut (Purbasari, 2015: 70).

Sahida et al., (2013) menjelaskan pembangunan sistem Islam berdasarkan prinsip larangan alikhtinaz (menimbun harta) dan prinsip ta'awun (tolong menolong). Prinsip melarang mendiamkan (menimbun) harta menyebabkan harta tersebut tidak produktif. Padahal, sektor ekonomi didorong oleh perputaran harta yang produktif melalui sektor perdagangan. Sehinga alikhtinaz (menimbun harta) menyebabkan ekonomi merosot dan petumbuhan ekonomi rendah.

Prinsip ta'awun (tolong menolong) diwujudkan salah satunya melalui konsep zakat yakni kewajiban umat Islam menyisihkan sebagian hartanya untuk orang yang berhak menerimanya. Sudarsono (2002: 232) menegaskan bahwa legitimasi hukum zakat ini sangat kuat yakni tiga puluh kali disebut dalam Al-Quran dan dua puluh tujuh kali disebut bersamaan dengan perintah sholat yakni "Dirikan sholat dan tunaikan zakat".

Pengertian zakat secara umum merupakan harta yang wajib dikeluarkan oleh setiap muslim untuk membersihkan ataupun menyucikan hartanya agar harta yang dimiliki menjadi berkah. Mengeluarkan zakat bukanlah mengurangi harta, akan tetapi terus berkembang dalam konteks kebajikan (Purbasari, 2015). Zakat dapat dijadikan sebagai salah satu bentuk modal bagi usaha kecil, maka zakat memiliki pengaruh yang besar pada berbagai hal 
kehidupan umat, di antaranya adalah pengaruh dalam bidang ekonomi dan pemerataan kesejahteraan secara adil (Sartika, 2008 :76-77).

Melihat manfaat dan potensi zakat yang dapat dijadikan modal dalam membangun bangsa terutama untuk peningkatan taraf hidup masyarakat dan sebagai sumber dana bagi penyediaan fasilitas umum lainnya, maka sangat beralasan jika pelaksanaan zakat dapat dipaksakan sesuai hukum asalnya melalui bantuan negara (negara harus memfasilitasi), yaitu pemerintah mengupayakan perundang-undangan zakat. Artikel ini akan membahas secara mendalam tentang optimalisasi zakat sebagai modal sosial Islam untuk mengatasi masalah ekonomi khususnya kemiskinan di Indonesia.

\section{Tinjauan Pustaka}

\section{Zakat Dalam Perspektif Sosial Dan Ekonomi}

Dalam istilah ekonomi, zakat merupakan suatu tindakan pemindahan harta kekayaan dari golongan yang kaya kepada golongan miskin. Transfer kekayaan berarti juga transfer sumber-sumber ekonomi (Yaqin, 2015). Herdianto (2012: 103) menyatakan bahwa dengan menggunakan pendekatan ekonomi, zakat bisa berkembang menjadi konsep kemasyarakatan (muamalah), yaitu konsep tentang bagaimana cara manusia melakukan kehidupan bermasyarakat termasuk di dalamnya bentuk ekonomi. Terdapat dua konsep yang selalu di kemukakan dalam pembahasan mengenai sosial ekonomi Islam yang saling berkaitan yaitu pelarangan riba dan perintah membayar zakat (Q.S al-Baqarah/2:276).

Zakat ditinjau dari pendekatan etnis dan pemikiran rasional ekonomis adalah sebagai kebijaksanaan ekonomi yang dapat mengangkat derajat orang-orang miskin, sehingga dampak sosial yang diharapkan dapat tercapai secara maksimal. Hal ini dapat terwujud jika distribusi kekayaan dilakukan secara adil. Distribusi Zakat sebaiknya diberikan kepada orangorang yang berhak, baik kepada satu atau lebih penerima zakat maupun kepada organisasi sosial yang mengurusi fakir miskin dengan tepat sasaran.

Dalam kitab hukum fiqh Islam, harta kekayaan yang wajib dizakati digolongkan dalam kategori : emas, perak dan uang (simpanan), barang yang di perdagangkan, hasil peternakan, hasil bumi dan hasil tambang dan barang temuan

\section{Modal Sosial}

Modal sosial dapat didefinisikan sebagai serangkaian nilai dan norma informal yang dimilki bersama diantara para anggota suatu kelompok masyarakat yang memungkinkan terjadinya kerjasama diantara mereka. Modal sosial sendiri merupakan kapabilitas yang muncul dari kepercayaan umum di dalam sebuah masyarakat atau di bagian-bagian tertentu darinya (Fukuyama \& Ruslani., 2002).

Fukuyama $(1995 ; 199)$ mendefinisikan modal sosial sebagai seperangkat norma atau nilai informal yang dimiliki bersama oleh para anggota suatu kelompok yang memungkinkan terjalinnya kerjasama di antara mereka. Selanjutnya menurut Fukuyama (1995) 


\section{Alingr Eurnal \& konomi \& Q Quangan đslam https://journal.trunojoyo.ac.id/dinar/index DOI: https://doi.org/10.21107/dinar

mengungkapkan kunci dari modal sosial adalah trust atau kepercayaan. Dengan trust, lanjut Fukuyama, orang-orang bisa bekerjasama dengan baik. Karena ada kesediaan diantara mereka untuk menempatkan kepentingan bersama di atas kepentingan pribadi. Trust bagaikan energi yang dapat membuat kelompok masyarakat atau organisasi dapat bertahan. Trust yang rendah mengakibatkan banyak energi terbuang karena dipergunakan untuk mengatasi konflik yang berkepanjangan.

Pembangunan tidak hanya berkaitan dengan modal ekonomi saja, namun juga modal sosial yang berkaitan dengan modal ekonomi. Modal sosial memiliki kekuatan untuk mempengaruhi prinsip-prinsip yang melandasi kemajuan ekonomi dan kesejahteraan sosial suatu negara. Negara yang modal sosialnya tinggi memiliki kecenderungan keberhasilan ekonomi yang tinggi dan berkualitas. Sebaliknya, Negara yang tingkat modal sosialnya rendah, cenderung memiliki kemajuan dan perilaku ekonomi yang lebih lamban dan inferior.

Dalam konteks Islam, Islam memiliki landasan kuat untuk membangun masyarakat yang committed terhadap modal sosial. Islam memiliki komitmen terhadap kontrak sosial dan norma yang telah disepakati bersama; dan bangunan masyarakat Muslim ciri dasarnya adalah ta'awun (tolong menolong), takaful (saling menanggung), dan tadhomun (memiliki solidaritas).

Postulat naqliyah ajaran Islam yang koheren dengan modal sosial terdokumentasikan dengan baik 15 abad silam (Mintarti, 2003). Saat itu, masyarakat di Kota Madinah diajarkan untuk membangun dan menjunjung masyarakat ideal yang kerap kita kenal dengan sebutan masyarakat madani atau civil society (Masyarakat yang menjunjung tinggi nilai-nilai peradaban).

Masyarakat ini, memiliki tantanan sosial yang baik, berasas pada nilai moral yang menjamin adanya kesimbangan antara hak dan kewajiban individu dengan hak dan kewajiban sosial. Implementasinya antara lain dengan terbentuknya good governance yang tunduk pada sistem dan perundang-undangan yang akuntabel dan transparan.

Dalam Islam dikenal doktrin fitrah yang sejalan dengan makna trust. Setiap bayi yang terlahir adalah laksana kertas putih bersih. Islam tidak mengenal dosa turunan. Manusia pada dasarnya adalah baik. Maka, dalam konteks relasi sosial, Islam menganjuran untuk berprasangka baik (busn al-dzan) dan melarang ghibah dan fitnah. Ajaran filosofis tersebut dipraktikkan dalam kehidupan sehari-hari Nabi Muhammad SAW, khususnya dalam berdagang sehingga beliau dikenal dengan sebutan al-Amin (orang yang terpercaya).

Tidak sedikit hadits nabi yang menekankan pentingnya modal sosial, baik diantara sesama Muslim maupun sesama manusia (lihat Mintarti, 2003). Anas ra. menyatakan bahwa Nabi SAW bersabda, "Tiada sempurna iman salah seorang dari kamu sehingga ia mencintai sesama Muslim, sebagaimana ia telah mencintai dirinya sendiri."

An-Nu'man Basyir ra. berkata: bersabda Rasulullah SAW, "Perumpamaan orangorang Mukmin dalam cinta mencintai, kasih mengasihi dan rahmat merahmati adalah 
bagaikan satu badan, apabila salah satu anggota badannya menderita sakit, maka menjalarlah penderitaan itu ke seluruh badan, hingga terasa panas dan tidak dapat tidur."

\section{Kemiskinan}

Kemiskinan adalah keadaan saat ketidakmampuan untuk memenuhi kebutuhan dasar seperti makanan, pakaian, tempat berlindung, pendidikan, dan kesehatan. Kemiskinan dapat disebabkan oleh kelangkaan alat pemenuh kebutuhan dasar, ataupun sulitnya akses terhadap pendidikan dan pekerjaan. Kemiskinan merupakan masalah global. Sebagian orang memahami istilah ini secara subyektif dan komparatif, sementara yang lainnya melihatnya dari segi moral dan evaluatif, dan yang lainnya lagi memahaminya dari sudut iLAZah yang telah mapan, dll.

Kemiskinan dipahami dalam berbagai cara. Pemahaman utamanya mencakup: Pertama gambaran kekurangan materi, yang biasanya mencakup kebutuhan pangan seharihari, sandang, perumahan, dan pelayanan kesehatan. Kemiskinan dalam arti ini dipahami sebagai situasi kelangkaan barang-barang dan pelayanan dasar. Kedua gambaran tentang kebutuhan sosial, termasuk keterkucilan sosial, ketergantungan, dan ketidakmampuan untuk berpartisipasi dalam masyarakat. Hal ini termasuk pendidikan dan informasi. Keterkucilan sosial biasanya dibedakan dari kemiskinan, karena hal ini mencakup masalah-masalah politik dan moral, dan tidak dibatasi pada bidang ekonomi. Gambaran kemiskinan jenis ini lebih mudah diatasi daripada dua gambaran yang lainnya. Ketiga gambaran tentang kurangnya penghasilan dan kekayaan yang memadai. Makna "memadai" di sini sangat berbeda-beda melintasi bagian-bagian politik dan ekonomi di seluruh dunia. Gambaran tentang ini dapat diatasi dengan mencari objek penghasilan di luar profesi secara halal. Perkecualian apabila institusi tempatnya bekerja melarang.

\section{Metode Penelitian}

\section{Jenis Penelitian}

Jenis penelitian dalam penelitian ini adalah kualitatif dengan pendekatan studi literatur dengan sumber data sekunder yang diperoleh dari penelitian-penelitian terdahulu, dan sumber referensi lainnya. Studi literatur adalah cara yang dipakai untuk menghimpun datadata atau sumber-sumber yang berhubungan dengan topik yang diangkat dalam suatu penelitian yang didapat dari berbagai sumber, jurnal, buku dokumentasi, internet dan pustaka (Danu, 2015). Penelitian ini memberikan gambaran secara diskriptif tentang potensi dana zakat yang begitu besar dan potensi itu perlu dioptimalkan guna mengatasi masalah ekonomi khususnya kemiskinan, sehingga pertumbuhan ekonomi akan meningkat, lebih lanjut pembangunan akan berjalan dengan baik.

\section{Jenis Data}


Jenis data dalam penelitian ini menggunakan data sekunder. Data sekunder adalah sumber data yang tidak langsung memberikan data kepada pengumpul data (Sugiyono, 2010: 402). Data sekunder merupakan data yang sifatnya mendukung keperluan data primer seperti buku-buku, penelitian-penelitian sebelumnya dan berbagai sumber bacaan yang berkaitan dengan zakat dan pengentasan kemiskinan.

\section{Metode Pengumpulan dan Analisis Data}

Metode pengumpulan data yang digunakan dalam penelitian ini menggunakan teknik triangulasi teori (Theory Triangulation). Data atau informasi dari satu pihak diperiksa kebenarannya dengan cara memperoleh informasi dari sumber lain (Abdulloh \& Saebani, 2014: 73). Tujuannya adalah membandingkan informasi tentang hal yang sama yang diperoleh dari berbagai referensi dan literatur agar ada jaminan tingkat kepercayaannya. Metode analisis data yaitu teknik analisis data deskriptif kualitatif yaitu dengan data-data yang diperoleh dari tinjauan literatur serta website terkait disusun menjadi sebuah fakta-fakta yang aktual untuk kemudian dilakukan pembahasan.

\section{Pembahasan}

Sesungguhnya ajaran Islam dengan konsep zakatnya, telah memberikan landasan mendasar bagi pertumbuhan dan perkembangan kekuatan sosial ekonomi umatnya. Ajaran ini memiliki dimensi yang kompleks yang tidak dimiliki oleh ajaran agama atau aliran-aliran pemikiran ekonomi klasik maupun modern lainnya. Dalam implementasinya, pendayagunaan dana zakat berorientasi pada penanganan kesejahteraan sosial dan pengentasan kemiskinan baik dalam jangka pendek maupun jangka panjang (Yaqin, 2015). Agar supaya harta kekayaan tidak hanya beredar di antara orang-orang kaya saja, tetapi diharapkan dapat memberi kontribusi kepada kesejahteraan masyarakat sebagai suatu keseluruhan.

Sistem ekonomi Islam melarang penumpukan kekayaan oleh sekelompok orang. Islam mengajarkan pemerataan kesejahteraan dengan melakukan distribusi harta, dalam hal ini adalah zakat. Zakat merupakan instrumen paling efektif dan esensial yang tidak terdapat dalam sistem kapitalis maupun sosialis. Secara ekonomi, zakat berfungsi distributif, yaitu: pendistribusian kembali (redistribusi) pendapatan dari muzakki kepada mustahik.

Zakat dikeluarkan pada waktu yang khusus, dalam artian bahwa sempurnanya kepemilikan itu selama setahun (hawl), baik harta berupa binatang ternak, uang, maupun barangdagangan, begitu juga terhadap biji-bijan (hasil sawah atau ladang), buah-buahan, barang tambang, penghasilan dan profesi (menurut sebagian ulama'), yang semuanya wajib dizakati. Zakat adalah penunaian hak yang wajib yang terdapat dalam harta. Zakat juga dimaksudkan sebagai bagian harta tertentu dan yang diwajibkan oleh Allah untuk diberikan kepada orang orang fakir. 
Menurut Yaqin, (2015) menyebutkan bahwa implementasi zakat merupakan komitmen yang kuat dan langkah yang kongkret dari negara dan masyarakat untuk menciptakan suatu sistem distribusi kekayaan dan pendapatan secara sistemik dan permanen. Upaya ini merupakan wujud nyata dari upaya menciptakan keadilan sosial dan mencerminkan komitmen sosial dari ekonomi Islam.

Di balik pesatnya kemajuan dunia perzakatan di Indonesia, masih terdapat banyak persoalan yang perlu diselesaikan diantaranya; kesenjangan potensi dan penghimpunan zakat, masih lemahnya perhatian masyarakat terhadap zakat, masalah kredibilitas lembaga, masalah SDM (Sumber Daya Manusia) amil, masalah regulasi zakat, masalah peran antar BAZ (LembagaAmil Zakat) dengan LAZ (Lembaga Amil Zakat) dan masalah efektivitas serta efisiensi program pemberdayaan zakat. Zakat sebagai instrument ekonomi dan kesejahteraan ummat, maka upaya mengoptimalkan pengelolaannya menjadi suatu keharusan karena merupakan salah satu pilar Islam yang berdimensi ubudiyyah, ijtimaiyyah dan iqtishadiyyah, yang dapat berkontribusi dalam meningkatkan kesejahteraan masyarakat dan merupakan penjalin tali kasih antara manusia (hablunminannas) begitu pula penghubung-komunikasi seorang hamba dengan Tuhannya(bablunminallah).

Problematika pengelolaan zakat diantaranya; keterbatasan skill dan sumber daya manusia (SDM) yang mumpuni dalam pengelolaan zakat danmasih lemahnya peraturanperaturanyang dapat meningkatkan pengoptimalan pengelolaan zakat.Sebagai solusi atas problematikatersebut adalah mensegerakan solusi solusi terhadap problem-problem yang terjadi pada organisasi pengelola zakat (OPZ), keterlibatan stakeholder (pemerintah) dalam mengatur mekanisme pengelolaan zakat dan menggalakkan edukasi kepada masyarakat tentang kewajiban dan potensi zakat sebagai instrumen ekonomi dan kesejahteraan.

Untuk mengoptimalkan dan menyelesaikan berbagai problem tentang pengelolaan zakat dan dalam mengoptimalkan peran zakat untuk mengentaskan kemiskinan maka perlu dilakukn beberapa hal, yaitu:

\section{Penerapan Good Coorporate Governence Lembaga Amil Zakat}

Komite Cadbury (Dahya, McConnell, \& Travlos, 2002) menjelaskan corporate governance sebagai sistem yang mengarahkan dan mengendalikan perusahaan dengan tujuan, agar mencapai keseimbangan antara kekuatan kewenangan yang diperlukan oleh perusahaan, untuk menjamin kelangsungan eksistensinya dan pertanggungjawaban kepada stakeholders. 110 Forum for Corporate Governance in Indonesia (FCGI) sebagaimana dikutip oleh M. Arief Effendi, mendefinisikan Corporrate Governance sebagai seperangkat peraturan yang mengatur hubungan antara pemegang saham, pengurus (pengelola) perusahaan, pihak kreditur, pemerintah, karyawan, serta para pemegang kepentingan internal dan

eksternal lainnya yang berkaitan dengan hak-hak dan kewajiban mereka atau dengan kata lain suatu sistem yang mengendalikan perusahaan dengan tujuan untuk menciptakan 


\section{ining Eurnal \&kiknomi \& Qeuangan बslam https://journal.trunojoyo.ac.id/dinar/index DOI: https://doi.org/10.21107/dinar

nilai tambah bagi semua pihak yang berkepentingan (stakeholders). Good Corporate Governance tidak lain adalah permasalahan mengenai proses pengelolaan perusahaan secara konseptual menyangkut diaplikasikannya prinsip-prinsip fairness, transparency, accountability, dan responsibility, terutama ditujukan kepada perusahaan-perusahaan publik, Badan Usaha Milik Negara (BUMN), perusahaan-perusahaan yang menggunakan dana publik dan ikut dalam pengelolaan dana publik.

Menurut Effendi, Good Corporate Governance secara definitif merupakan sistem yang mengatur dan mengendalikan perusahaan untuk menciptakan nilai tambah (value added) untuk semua stakeholders. Prinsip utama dari Good Corporate Governance yang ditawarkan oleh Organization for Economic Cooperation and Development (OECD) yang telah di sebutkan oleh FCGI sebagaimana dikutip oleh Indra dan Ivan, yaitu Fairness (kewajaran) yaitu menekankan bahwa semua pihak yang terlibat harus diperlakukan sama atau setara, Transparency (transparansi) yaitu prinsip yang sangat penting bagi stakeholder untuk mendapat informasi, Accountability (akuntabilitas) adalah kejelasan fungsi, struktur, sistem dan pertanggungjawaban organ perusahaan sehingga pengelola perusahaan terletak secara efektif, dan Responsibility (tanggungjawab) adalah kesesuaian pengelolaan perusahaan terhadap peraturan perundang-undangan yang berlaku dan prinsip korporasi yang sehat.

Prinsip Good Corporate Governance juga dapat diterapkan dalam pengelolaan organisasi zakat. BAZNAS maupun LAZ sebagai organisasi nirlaba juga dapat mengadopsi konsep Good Corporate Governance yang meliputi prinsip transparency, prinsip accountability dan prinsip responsibility dan prinsip independency.

Pertama, prinsip transparency, suatu keterbukaan dalam menyampaikan informasi mengenai sistem perencanaan zakat dan sistem pemantauan penyaluran zakat. Prinsip dasar pada transparency mengandung unsur mengungkapkan (disclosure) dan penyediaan informasi yang memadai dan mudah diakses oleh pemangku kepentingan. Lembaga Amil Zakat harus mengambil inisiatif untuk mengungkapkan, tidak hanya masalah yang disyaratkan oleh peraturan perundang-undangan, tetapi juga hal yang penting untuk pengambilan keputusan oleh pemegang saham, kreditur dan pemangku kepentingan lainnya.

Adapun pedoman pokok pelaksanaan prinsip transparancy mencakup dua hal yaitu: Lembaga Amil Zakat harus mempunyai kebijakan untuk mengungkapkan berbagai informasi penting yang diperlukan oleh pemangku kepentingan dan Lembaga Amil Zakat harus mengungkapkan informasi secara tepat waktu, memadai, jelas, akurat dan dapat diperbandingkan serta mudah diakses oleh pemangku kepentingan sesuai dengan haknya.

Implementasi dari prinsip (transparany) dalam Lembaga Amil Zakat yaitu dengan melibatkan pemangku kepentingan untuk hadir mengikuti rapat maupun sosialisasi program. Bukan hanya dari unsur pimpinan melainkan juga dari tokoh masyarakat, ulama' dan tenaga 


\section{Ding Eurnal \&.konomi \& Qeuangan बslam https://journal.trunojoyo.ac.id/dinar/index DOI: https://doi.org/10.21107/dinar

profesional yang nantinya akan memberikan informasi juga kepada masyarakat seputar program dan sekaligus untuk menarik calon-calon murakeki untuk berzakat.

Kedua, selalu menyajikan informasi secara baik dan jelas kepada muzakki. Informasi ini berupa pemasukan, pengeluaran jumlah dana zakat dan program-program Lembaga Amil Zakat. Muzakki dengan mudah mengetahui informasi seputar informasi Lembaga Amil Zakat melalui kantor layanan dan akses informasi melalui media online (facebook, instagram, e-mail) dan media cetak seperti majalah yang setiap bulannya diterbitkan.

Kedua prinsip accountability yaitu suatu kepastian penggunaan dana melalui sistem pelaporan zakat. Prinsip dasar pelaksanakan prinsip akuntabilitas (accountability) adalah akuntabilitas mengandung unsur kejelasan fungsi dalam organisasi dan cara mempertanggung jawabkannya. Lembaga Amil Zakat harus dapat mempertanggung jawabkan kinerjanya secara transparan dan wajar. Untuk itu perusahaan harus dikelola secara benar, terukur dan sesuai dengan visi dan misi dari Lembaga Amil Zakat dengan tetap memperhitungkan kepentingan stack holder. Akuntabilitas merupakan prasyarat yang diperlukan untuk mencapai kinerja yang berkesinambungan. Adapun pedoman pokok pelaksanaan prinsip akuntabilitas salah satunya adalah perusahaan harus menetapkan tugas dan tanggung jawab yang jelas dari masing masing organ dan seluruh jajaran perusahaan dan seluruh karyawan yang selaras dengan visi, misi, nilai-nilai perusahaan (corporate values), sasaran usaha dan strategi perusahaan.

Indikator penerapan akuntabilitas dari sistem Good Corporate Governance adalah kejelasan fungsi dalam organisasi dan cara mempertanggungjawabkannya. Apabila dikaitkan dengan penerapan prinsip akuntabilitas dalam penghimpunan dana zakat di Lembaga Amil Zakat yaitu kejelasan fungsi di Lembaga Amil Zakat berjalan dengan baik. Hal ini terlihat dari pembagian struktur organisasi yang di bentuk Lembaga Amil Zakat sesuai dengan bidangnya masing-masing. SDM yang dimiliki Lembaga Amil Zakat merupakan SDM yang professional. Setiap anggota mendapatkan perannya masing-masing dan setiap akhir bulan mempertanggung jawabkan tugas-tugasnya dalam rapat yang diikuti pimpinan Lembaga Amil Zakat.

Manajemen LAZ harus memiliki bagian-bagian dari struktur organisasi yang jelas serta pembagian tugas dan fungsi yang memudahkan kegiatan operasional kantor maupun lapangan. Sistem pendelegasian tanggung jawab memiliki tujuan agar tidak terjadi penumpukan atau duplikasi pekerjaan. Lembaga Amil Zakat juga harus meningkatan efisien dan efektifitas dalam memperbaiki manajemen. Seperti adanya peningkatan profesionalisme melalui penempatan para petugas yang sesuai dengan keahliannya karena dalam penanganan tugas kantor maupun tugas lapangan harus ditangani oleh para tenaga yang professional. Untuk itu, perlu diadakan pendidikan dan pelatihan yang sesuai dengan kebutuhannya. 


\section{Alingr Eurnal \&.konomi \& Qeuangan बslam https://journal.trunojoyo.ac.id/dinar/index DOI: https://doi.org/10.21107/dinar

Ketiga prinsip responsibility yaitu tanggung jawab sosial terhadap masyarakat dan stakeholders berdasarkan manajemen modern, untuk berlangsungnya kejelasan fungsi struktur organisasi. Pedoman dasar pelaksanakan prinsip tanggung jawab (responsibility) adalah perusahaan harus mematuhi peraturan perundang-undangan dan melaksanakan tanggung jawab terhadap masyarakat dan lingkungan sehingga dapat terpelihara kesinambungan usaha dalam jangka panjang dan mendapat pengakuan sebagai warga lembaga yang baik (good corporate citizen).

Indikator penerapan tanggung jawab (responsibility) dari sistem Good Corporate Governance adalah setiap organ Perusahaan dan seluruh jajarannya harus berpegang pada prinsip kehati-hatian dan menjamin dilaksanakannya peraturan perundang-undangan, anggaran dasar serta peraturan perusahaan. Perusahaan juga harus bertindak sebagai warga lembaga yang baik (good corporate citizen) termasuk peduli terhadap lingkungan dan melaksanakan tanggung jawab sosial.

Penerapan prinsip tanggung jawab (responsibility) pada Lembaga Amil Zakat maka setiap lembaga amil zakat harus selalu memperhatikan kepatuhan pada peraturan perundangundangan yang berlaku. Lembaga amil zakat harus mengikuti Undang-Undang yang berlaku seperti dalam pengelolaan zakat, lembaga amil zakat mengikuti dasar peraturan program pada Undang-Undang No.23 Tahun 2011 tentang Pengelolaan Zakat, peraturan pemerintah No.14 Tahun 2014 tentang Pelaksanaan Undang-Undang Nomor 23 Tahun 2011 tentang Pengelolaan Zakat.

Keempat prinsip independency yaitu lembaga amil zakat harus dikelola secara independen sehingga masing-masing organ perusahaan beserta jajarannya tidak boleh saling mendominasi dan tidak dapat diintervensi oleh pihak manapun. Lembaga amil zakat merupakan lembaga badan pemerintahan nonstruktural yang independen yang berkedudukan dibawah BAZNAS. Hal ini berdasar pada Peraturan Pemerintah No. 14 tahun 2014 Pasal 2 tentang Pelaksanaan Undang-Undang No.23 Tahun 2011 tentang Pengelolaan Zakat yang berbunyi BAZNAS berstatus sebagai lembaga pemerintah nonstruktural yang bersifat mandiri dan bertanggung jawab kepada Presiden melalui Menteri.

Pemerintah maupun lembaga lain tidak boleh ikut campur dalam mengatur kebijakan dari program-program LAZ, baik dalam hal perencanaan, pengumpulan, pendistribusian dan pendayagunaan dana ZIS. LAZ dapat bersinergi dengan Pemerintah maupun lembaga lain jika sesuai dengan visi dan misi dari lembaga amil zakat seperti memiliki tujuan sama yakni mengentaskan kemiskinan dan menciptakan kesejahteraan masyarakat. Atas dasar itu, lembaga amil zakat dapat menjalin kerjasama dengan dinas-dinas terkait dalam hal pemberian bantuan. 


\section{Digitalisasi Sistem Pengelolaan Zakat}

Digitalisasi pengelolaan zakat akan mempermudah pelaksanaan zakat, mempermudah pengelolaan dana zakat di lembaga zakat, dan memudahkan pendistribusian zakat kepada mereka yang berhak. Digitalisasi sistem zakat juga dapat meningkatkan transparansi, efektifitas, dan efisiensi dalam manajemen zakat. Dari sisi para badan dan lembaga zakat, teknologi dinilai dapat mempermudah proses pemasaran hingga pendistribusian dana zakat sehingga lebih tepat guna. Sedangkan bagi wajib zakat (muzaki), keberadaan teknologi akan mempermudah pembayaran zakat, dan memungkinkan mereka untuk memonitor pendistribusian dana zakat yang diserahkan.

Faktanya, era digital saat ini telah nyata digunakan untuk berbagai kebutuhan umat. Digitalisasi pengelolaan zakat dengan memanfaatkan berbagai ragam teknologi digital, misalnya, dalam bidang pengumpulan zakat, lembaga amil zakat dapat mengembangan multiplatform dan menguatkan sistem informasi yang berjejaring secara nasional ke berbagai provinsi dan kota.

Untuk memaksimalkan digitalisasi sistem zakat ini, maka setidaknya ada 3 hal yang harus diperhatikan. Pertama, peningkatan kesadaran wajib zakat dengan melakukan sosialisasi dan edukasi yang dapat dengan mudah difahami oleh masyarakat. Penggunaan teknologi dapat mempermudah penyebaran berbagai pesan seputar kewajiban membayar zakat bagi para muzaki tetapi tetap harus dikemas dengan bentuk yang mudah dipahami oleh masyarakat. Kedua, digitalisasi sistem zakat harus dapat menyentuh pelaporan penyaluran zakat agar masyarakat dapat mengetahui seluk-beluk pengelolaan dan penyaluran harta yang telah disisihkannya. Hal ini bertujuan untuk mendorong transparansi pengelolaan zakat dan meningkatkan kredibilitas lembaga amil zakat. Ketiga Peran pihak pemerintah dalam memudahkan dan mensukseskan program digitalisasi zakat dengan berupaya menerbitkan peraturan-peraturan terkait digitalisasi zakat yang dapat diaplikasikan di badan maupun lembaga zakat.

\section{Sinergi, kolaborasi dan kerjasama}

Sinergi, kolaborasi dan kerjasama merupakan fase ke empat dalam fase program gerakan zakat di Indonesia. Karena itu adanya kerjasama antar lembaga sangat penting dilakukan sebagai salah satu bentuk instrumen strategis bagi perkembangan kesejahteraan masyarakat secara nasional. Sinergi gerakan kerjasama dan kolaborasi ini turut memperkuat kegiatan filantropi dan menjadi alternatif untuk mengurangi kesenjangan di Indonesia dan Gerakan ini diharapkan mampu mempercepat, mengintegrasikan, dan memperbesar terjalinnya sinergi dan kolaborasi antar organisasi pengelola zakat, khususnya dalam upaya mengoptimalkan penyaluran dana zakat untuk meningkatkan kesejahteraan masyarakat.

Lembaga yang baik bukanlah lembaga yang bisa melakukan penghimpunan paling besar, tapi adalah yang paling banyak portofolio manfaatnya bagi mustahik maka Lembaga 
amil zakat seharusnya menganalisa potensi dari tiap lembaga dan melihat kemungkinan kerjasama dan kolaborasi yang bisa dilakukan dari tiap lembaga, baik pada lembaga pemerintahan dan swasta. Kerjasama dan kolaborasi itu bisa dilakukan dalam bentuk dakwah, sosial dan kemanusiaan, kesehatan, dan pemberdayaan.

Lembaga amil zakat perlu melakukan kerjasama dengan berbagai platform perniagaan elektronik (e-commerce) di Indonesia, misalnya dalam rangka penghimpunan dana dan optimasi program pemberdayaan masyarakat. Kerjasama dengan berbagai platform perniagaan ini lembaga amil zakat dapat memastikan produk pembinaan berstandar prasyarat kualitas pasar dan volumenya bisa berlanjut atau kontinuity dan dapat memastikan adanya kesadaran di lembaga zakat untuk melirik jaringan pasar yang lebih luas. Lemabaga amil zakat juga berpeluang mendapatkan digital capacity building dari platform perniagaan tidak hanya diberikan untuk mustahik tapi juga bagi amil zakat. Selanjutnya pelatihan kewirausahaan dan digital marketing bisa didapat guna memperluas jaringan dan pasar bagi para penerima manfaat. Dengan adanya kolaborasi ini, lemabaga amil zakat akan membuka kanal pemasaran digital bagi produk hasil pemberdayaan LAZ. Hal ini tentu akan mempertemukan produk-produk hasil pemberdayaan LAZ dengan para pembeli di era digital saat ini.

Lembaga amil zakat perlu juga membangun kolaborasi dan kerjaasama dengan Lembaga keuangan mikro, misalnya BMT (Baitul Mal Wat Tamwil), Koperas Jasa Keuangan Syariah (KJKS) dan Bank Wakaf Miro yang telah dikembangkan oleh pemerintah bekerjasama dengan pondok pesantren. Kerjasama ini perlu dilakukan untuk memberikan daya tarik zakat pada kalangan masyarakat kecil.

\section{Kesimpulan}

Untuk mengoptimalkan peran zakat sebagai modal sosial yang dapat mengentaskan kemiskinan, maka lembaga amil zakat perlu melakukan langkah strategis, yaitu penerapan good corporat governence pada lembaga amil zakat, menerapkan digitalisasi sistem pengelolaan lembaga amil zakat dan melakukan sinergi kolaborasi dan kerjasama denga lembaga lain yang sesuai dengan visi dan misi lembaga amil zakat. Program ini akan mendorong kesadaran kepercayaan masyarakat pada lembaga amil zakat. Strategi yang dilakukan juga akan mendorong kemudahan dalam pengelolaan, penghimpunan dan pendistribusian dana zakat sehingga dapat meningkatkan muzakki sekaligus meningkatnya dana zakat yang selanjutnya dapat didistribusikan dan dilaporkan secara transparan dan akuntabel.

\section{Daftar Pustaka}

Abdulloh, S. B., \& Ahmad, B. (2014). Metode Penelitian Ekonomi Islam Muamalah. Bandung: CV Pustaka Setia.

Dahya, J., McConnell, J. J., \& Travlos, N. G. (2002). The Cadbury Committee, corporate 
performance, and top management turnover. Journal of Finance. https://doi.org/10.1111/1540-6261.00428

Danu, A. E. (2015). Memahami Metode Penelitian Kualitatif Teori dan Praktik. Yogyakarta: Calpulis.

Fathurrahman, A. (2012). Kebijakan Fiskal Indonesia Dalam Perspektif Ekonomi Islam: Studi Kasus Dalam Mengentaskan Kemiskinan. Jurnal Ekonomi Dan Studi Pembangunan.

Fukuyama, F., \& Ruslani. (2002). Trust: kebajikan dan penciptaan kemakmuran. Penerbit Qalam.

Harry Azhar Aziz, Widiastuti, T., Mawardi, I., \& dkk. (2017). Zakat dan Pemberdayaan. Surabaya: Airlangga University Press (AUP).

Herdianto, A. W. (2012). Peran Negara Dalam Mengoptimalkan Zakat Di Indonesia. JURISDICTIE. https://doi.org/10.18860/j.v0i0.1729

Purbasari, I. (2015). Pengelolaan Zakat Oleh Badan Dan Lembaga Amil Zakat Di Surabaya Dan Gresik. Mimbar Hukum - Fakultas Hukum Universitas Gadjah Mada. https://doi.org/10.22146/jmh.15911

Sahida, N., Pusat, M., Ekonomi, P., Ekonomi, F., Pengurusan, D., \& Pusat, S. A. (2013). Pembangunan Menurut Perspektif Islam: Satu Analisis Awalan (Development from Islamic Perspective: An Interim Analysis). Johor Bahru.

Sartika, M. (2008). Pengaruh Pendayagunaan Zakat Produktif terhadap Pemberdayaan Mustahiq pada LAZ Yayasan Solo Peduli Surakarta. La_Riba, 2(1), 75-89. https://doi.org/10.20885/lariba.vol2.iss1.art6

Sudarsono, H. (2002). Konsep ekonomi Islam: suatu pengantar (Pertama). Yogyakarta: Ekonisia.

Sugiyono. (2010). Metode Penelitian Bisnis. Pendekatan Kuantitatif, kualitatif dan R \& D. Bandung: Alfabeta.

Yaqin, A. (2015). Optimalisasi Zakat Produktif Dalam Pengentasan Problem Kemiskinan. IQTISHADIA: Jurnal Ekonomi \& Perbankan Syariah. https://doi.org/10.19105/iqtishadia.v2i2.849 